\title{
Marketing in the Context of COVID-19
}

\author{
GUEST EDITORS \\ Andreia Silva * \\ Sandrina Teixeira ** \\ Maria Antónia Rodrigues *** \\ Jorge Remondes $* * * *$
}

\section{INTRODUCTION}

The current context has revealed the weaknesses of the contemporary world in several areas, but, above all, it has again emphasized the vulnerabilities of personalities, governments, parties, companies and organizations concerning the management of crisis communication and how you deal with risk (Jong, 2020, 2021), failure and the unexpected (McGuire, Cunningham, Reynolds, \& Matthews-Smith, 2020).

Inevitably, social networks have come to accelerate dissemination and, as a result, image and reputation become sensitive elements of an ecosystem that requires parsimony when it comes to matching stakeholder expectations (Coombs, 2007; Coombs \& Holladay, 2010). This new world requires strategy when communicating about human and property losses, but also aims to avoid credibility breakdowns and disastrous damage to notoriety and reputation (Mocho, 2021).

\footnotetext{
* Higher Institute of the Entre Douro and Vouga Region, Portugal. E-mail: a.silva@doc.isvouga.pt

** Polytechnic of Porto, Porto Accounting and Business School, Portugal. E-mail: sandrina@iscap.ipp.pt

*** Polytechnic of Porto, Porto Accounting and Business School, Portugal. E-Mail: mar@iscap.ipp.pt

**** Higher Institute of the Entre Douro and Vouga Region, Polytechnic of Porto, Porto Accounting and Business School, Portugal. E-Mail: j.remondes@doc.isvouga.pt
} 
Sitting in front of the screens, the different audiences watched more aware of how to communicate and act, especially in moments of tension and rupture. Despite the numerous lessons learned throughout history, and dissected in case studies that have become a reference, there is still much to be done to make organizations and people more skilled and resilient in communicating properly (Forni, 2019). At a time when anticipation and prevention require well-structured plans and accessible application, including management and appropriate response to events and reactions, until the evaluation, when conclusions are drawn from the procedures and results (Coombs, 2007; Mitroff, 1987), it is important to discuss communication, now from the perspective of an event that has truly turned the world into a global village.

After the lessons learned since the 1980s with the Tylenol, Bhopal, Chernobyl cases, going through major crises that shook the brands, organizations and governments capabilities such as the tragic events of Exxon Valdez, Malaysia Airlines, Hurricane Katrina, La Tocha, Fukushima, or the BP case (Gonçalves, 2011) the need to know better how to manage emotions responding to borderline situations emerges (Jin, Pang \& Cameron, 2010).

In the last decade, the imminence of anomalous situations with global effects, namely those related to information leaks (Davidoff, 2019), cyberattacks and the now recurrent concern of cyberterrorism, have forced the rethinking of theories and identification of good practices.

\section{STRUCTURE}

This special issue on Marketing in the Context of COVID-19 of the International Journal of Marketing, Communication and New Media (IJMCNM) publishes five relevant contributions about:

1. The Voice of the Consumer on sVoD Systems During Covid-19: A Service Opportunity Mining Approach;

2. Functionalities of Social Commerce used by SME During Pandemic;

3. Effects of E-business Adoption on Organizational Agility in the COVID-19;

4. Consumer Behavior: A Literature Review of the Early Research on the COVID- 


\section{Outbreak;}

\section{Digital Strategies to Combat the Impacts of the Covid-19 Pandemic in the Business Context}

The first article is dedicated to studying service improvement opportunities for subscription-based video-on-demand ( $\mathrm{sVoD}$ ) services by exploring customer-generated eWOM messages. The study understands the effects of the COVID-19 pandemic on expectations, real feelings and attitudes of customers towards its subscription-based video-on-demand services and compares these emotions with those of the pre-pandemic period.

The second article addresses social commerce functionalities used by enterprises to remain competitive in the market during the lockdown. In this paper these functionalities have been evaluated and examined in order to find their advantages and disadvantages.

In the third article, the authors developed a study that aimed to study the effects of adopting e-business systems on business agility. For this, they identified that knowledge management is the basis for companies to implement e-business systems.

The outbreak of COVID-19 has substantially altered trends and the research agenda in Consumer Behavior (CB). The main objectives of the fourth article are to analyze and classify the main contributions published in the early research on Consumer Behavior (CB) on the COVID-19 pandemic, seeking to discover the perspective and the gaps and outline future avenues of research.

In the last, fifth article, the authors focused on exploring the main digital strategies carried out by companies to mitigate/exploit the effects of the current pandemic situation.

The papers evaluated by the double-blind review system belong to authors who have presented the results of their studies that fit in the scientific areas of the IJMCNM; so, they were accepted for publication in this international scientific journal.

\section{ACKNOWLEDGEMENTS}

The guest editors of this special issue would like to thank the authors who have submitted their manuscripts to this special issue and the reviewers for their valuable 
contributions. We hope that this special edition on Marketing in the Context of COVID19 meets the expectations of our readers.

A final thanks to Web of Science ESCI, Crossref, Qualis CAPES, Google Scholar, ERIH Plus, REDIB, RCAPP, MIAR, OAJI, LATINDEX, DRJ, INDEX COPERNICUS, LIVRE for the support given to the positioning of IJMCNM in the scientific community.

\section{REFERENCES}

Coombs, W.T. (2007). Ongoing Crisis Communication. Sage.

Coombs, W.T. \& Holladay, S. (2010). The handbook of crisis communication. Wiley.

Davidoff, S. (2019). Data breaches: Crisis and Opportunity. Addison-Wesley Professional.

Forni, J. J. (2019). Gestão de Crises e Comunicação. Gen Atlas.

Gonçalves, G. (2011). Narrativas de defesa e culpa nos discursos organizacionais, in Pragmática: Comunicação Publicitária e Marketing. Estudos de Comunicação. Labcom.

Jin, Yan; Pang, Augustine; \& Cameron, Glen T. (2010).The role of emotions in crisis responses: Inaugural test of the integrated crisis mapping (ICM) model. (2010). Corporate Communications: An International Journal. 15, (4), 428-452. Research Collection Lee Kong Chian School Of Business.

McGuire, D., Cunningham, J. E. A., Reynolds, K., \& Matthews-Smith, G. (2020). Beating the virus: An examination of the crisis communication approach taken by New Zealand Prime Minister Jacinda Ardern during the Covid-19 pandemic. Human Resource Development International. https://doi.org/10.1080/13678868.2020.1779543

Mitroff, I. (1987). Effective Crisis management. Academy of Management Perspetives 1(3): 283-292. 10.5465/AME.1987.4275639.

Mocho, A. J. (2021). Crise nas empresas. Comunicação com os Media. Bnomics.

Jong, W. (2020). Public leadership in times of crisis: Lessons to learn from a crisis communication point of view. Communication Teacher. 10.1080/17404622.2020.1824296.

Jong, W. (2021). Evaluating Crisis Communication. A 30-item Checklist for Assessing Performance during COVID-19 and Other Pandemics. Journal of Health Communication. 10.1080/10810730.2021.1871791.

\section{How to cite this article:}

Silva, A.; Teixeira, S.; Rodrigues, M. A.; \& Remondes, J. (2022). Marketing in the Context of COVID-19, International Journal of Marketing, Communication and New Media. Special Issue on Marketing in the Context of COVID-19, January 2022, 1-4. 